\title{
Structural variation in the brown alga Sargassum cymosum and its effects on associated amphipod assemblages
}

\author{
Leite, FPP. ${ }^{\mathrm{a}}$, Tanaka, MO. ${ }^{\mathrm{b}}$ and Gebara, $R S .^{\mathrm{a}}$ \\ aDepartamento de Zoologia, Instituto de Biologia, Universidade Estadual de Campinas - UNICAMP, \\ CP 6109, CEP 13083-970, Campinas, SP, Brazil \\ ${ }^{\text {b}}$ Departamento de Hidrobiologia, Universidade Federal de São Carlos - UFSCar, \\ CP 676, CEP 13565-905, Rodovia Washington Luis, Km 235, São Carlos, SP, Brazil \\ *e-mail: fosca@unicamp.br \\ Received February 21, 2005 - Accepted December 13, 2005 - Distributed May 31, 2007
}

(With 3 figures)

\begin{abstract}
The presence of diverse biological substrates adds complexity to coastal landscapes and increases the number of ecological niches that can be used by the mobile epifauna. Studies on the influence of structural complexity have focused mainly on algal host species, but there is little information about the influence of intraspecific structural variation on the associated mobile epifauna. In this work, we examined whether intraspecific variation in the brown alga Sargassum cymosum influenced the structure of amphipod assemblages on two shores with different wave exposure. At least 15 fronds were randomly sampled at Fortaleza and Perequê-Mirim beaches, on the Atlantic coast of São Paulo state, southeastern Brazil, and 12 variables were measured for each alga. The amphipods were identified and counted. The greatest structural variation in S. cymosum occurred within shores, whereas the differences between shores were mainly related to algal size. These characteristics influenced amphipod assemblages differently on each shore, with the greatest effects being associated with variables related to morphological complexity, such as holdfast size, the number and size of branches, and the extent of cover by sessile colonial animals. These findings show that monospecific algal banks are not homogeneous, and that morphological differences and interactions with other biological substrates can influence the mobile epifaunal assemblages.
\end{abstract}

Keywords: Sargassum cymosum, amphipods, structural variation, morphology.

\section{Variação estrutural da alga parda Sargassum cymosum e seu efeito sobre as assembléias dos anfípodes associados}

\begin{abstract}
Resumo
A presença de substratos biológicos aumenta a complexidade dos ambientes costeiros, proporcionando maior número de nichos ecológicos para a epifauna vágil. Estudos sobre os efeitos da complexidade estrutural das algas têm enfocado principalmente as espécies presentes entre os seus ramos, porém há poucos dados sobre a influência da variação estrutural intra-específica sobre essa fauna. Neste trabalho, foi analisada a influência da variação da alga parda Sargassum cymosum sobre a estrutura da assembléia de anfípodes entre duas praias com diferentes graus de exposição às ondas, e em cada uma delas, no SE do Brasil. Pelo menos 15 frondes foram individualmente coletadas aleatoriamente nos costões das praias de Fortaleza e Perequê-Mirim, e diversas variáveis (12) foram medidas para cada fronde de alga. Os anfípodes foram identificados e contados. As maiores variações nas características de S. cymosum foram obtidas em cada praia, enquanto que diferenças entre as praias foram principalmente relacionadas ao tamanho das algas. Estas características influenciaram as assembléias de anfípodes de maneira diferente em cada praia, sendo que os maiores efeitos foram atribuídos a variáveis relacionadas com a morfologia das algas como o tamanho do apressório, o número e tamanho dos ramos e a cobertura por organismos coloniais sésseis. Portanto, bancos monoespecíficos de algas não são homogêneos e tanto as diferenças morfológicas como as interações com outros substratos biológicos podem influenciar as assembléias da epifauna vágil.
\end{abstract}

Palavras-chave: Sargassum cymosum, anfípodes, variação estrutural, morfologia. 


\section{Introduction}

Biological substrates have a major influence on the organization of shallow water communities by diversifying the range of spatial resources that can be used, by increasing the area available for colonization by sessile species, and by providing refuges against predators and unfavourable environmental conditions (Downes et al., 2000; Monteiro et al., 2002). Aquatic macrophytes form an important secondary substrate that can be used by epifaunal species, mainly in rocky shore environments (Jenkins and Wheatley, 1998; Schreider et al., 2003), and the local diversity of macrophytic species provides a variety of secondary substrates for the associated fauna (Edgar, 1983; Hull, 1997; Parker et al., 2001). Substrate diversity results from differences in algal morphology (Hacker and Steneck, 1990; Hull, 1997), the presence of defense compounds against omnivorous consumers (Hay et al., 1987; Jormalainen et al., 2001), and structural complexity among macrophytes, with more ecological niches being produced when algae have more complex morphologies (Gee and Warwick, 1994). Hence, the increase in resources that can be explored either because of lower predation rates or simply because of a greater number of spatial structures that can be used, can influence the patterns of diversity of the associated fauna (Parker et al., 2001; Kelaher, 2003a,b).

The presence of epiphytic organisms can also result in variation among biological substrates (Russo, 1990; Jernakoff et al., 1996). Algal epiphytes can increase the complexity of aquatic macrophytes, resulting in greater diversity of the associated mobile species (Holmquist, 1997; Jernakoff and Nielsen, 1998). Similarly, the presence of colonial organisms such as sponges, hydrozoans, and bryozoans can increase macrophytic complexity (Hall and Bell, 1988). Hence, several factors can influence the distribution of the mobile fauna within and among macrophytic species (Flynn et al., 1996, Horinouchi and Sano, 1999).

Few studies have compared the fauna associated with structural variations within a given macrophytic species (e.g., Jenkins et al., 2002), although considerable variation among assemblages has been reported within $1 \mathrm{~m}$ of distance of single fronds (Tanaka and Leite, 2003). For example, Gunnill (1982a) found differences among isolated and aggregated individuals of Pelvetia fastigiata, which suggested that the organization of the mobile epifauna was related to differences among algal patches. In contrast, Sanchez-Moyano et al. (2001) reported that variation in the associated fauna was related to the life cycle of Caulerpa prolifera. In within-species comparisons, the greatest differences in the species richness and composition of the associated fauna have been associated with size-related characteristics of macroalgae (Russo, 1990; Attrill et al.; 2000, Kelaher, 2003a,b).

The genus Sargassum has the most complex morphology within the Fucales (Széchy and Paula, 1998). Sargassum species common in southeastern Brazil, such as S. cymosum and S. stenophyllum, show marked inter-individual variation in characters such as frond size, number and size of primary stalks and secondary branches, and holdfast size (Széchy and Paula, 1998). This variation occurs within and among shores, and results from differences in hydrodynamics, depth, age, and phenology (Paula, 1988; Széchy and Paula, 1998). As discussed above, the presence of epiphytic organisms can contribute strongly to variation among individuals and can influence the structure of the associated fauna (Attrill et al., 2000).

In this study, we examined whether structural differences among individuals of $S$. cymosum between and within shores influenced the species richness and composition of the associated mobile fauna, with particular emphasis on amphipods, the dominant group. Specifically, we assessed 1) whether algal structure differed between and within two shores with distinct hydrodynamics, and 2) whether structural differences among algae influenced the structure of amphipod assemblages between and within shores.

\section{Methods}

\subsection{Study area}

Extensive banks of the brown alga Sargassum occur in the sublittoral fringe on rocky shores in southeastern Brazil (Széchy and Paula, 2000). We selected two shores in the municipality of Ubatuba (23 $32^{\circ}$ ' S; and $45^{\circ} 10^{\prime} \mathrm{W}$ ) that differed in wave exposure, namely, Perequê-Mirim (sheltered) and Fortaleza (exposed). Dense banks of $S$. cymosum occur on both shores, although the algae on the exposed shore have smaller fronds, mainly because of differences in hydrodynamics (Paula, 1988). Sampling was done in April and May 1997, the period of highest mobile fauna density in this region (Tanaka and Leite, 2003).

\subsection{Sampling and algal descriptions}

Sixteen fronds of S. cymosum were randomly sampled at Fortaleza and 15 at Perequê-Mirim. Each frond was gently placed in a plastic bag underwater and the holdfast was detached with a putty knife. In the laboratory, each frond was transferred to a bucket containing seawater with a few drops of formaldehyde to help remove the mobile fauna, and the resulting material was washed through a $250 \mu \mathrm{m}$ mesh sieve; this procedure was repeated four times. This mesh size retained juvenile and adult individuals of the macrofauna; meiofaunal species were not analysed. All animals were preserved in $70 \%$ alcohol and identified using a stereomicroscope.

To determine whether structural variation in $S$. cymosum influenced the structure of the associated assemblages, the following variables were measured for each frond, according to Széchy and Paula (1998):

a) wet mass: each frond was placed on absorbent paper for 30 minutes to remove excess water and then weighed to the nearest $0.01 \mathrm{~g}$; 
b) maximum length: distance from the holdfast to the tip of the longest stem, measured with a caliper to the nearest $0.05 \mathrm{~mm}$;

c) number of primary stalks and secondary branches;

d) diameter of a primary stalk at the base (DB1), in the intermediate region (DM1), and at the first bifurcation (DP1), measured with a caliper to the nearest $0.05 \mathrm{~mm}$;

e) maximum (DIAM) and minimum (DIAMEN) diameters of the holdfast, measured with a caliper to the nearest $0.05 \mathrm{~mm}$;

f) leaf area (LA), measured digitally with a scanner in pixels and later converted to $\mathrm{cm}^{2}$; and

g) epiphytism by algae (EPFA) or sessile colonial animals (EPFB), classified into six classes of abundance - absent, very low, low, medium, high, very high - with values ranging from 0 to 5 , respectively.

\subsection{Data analysis}

Principal components analysis (PCA) with centered and standardized data was used to assess whether the structural characteristics of $S$. cymosum differed between shores. We evaluated whether the algal characteristics influenced total abundance, species richness, and the Shannon-Weaver diversity between and within shores by using multiple regression with stepwise forward selection of variables for the complete dataset and separately for each shore. The effects of multicollinearity were avoided by using a pairwise correlation analysis among independent variables; three variables (DIAMEN, NR2 and DM1) were excluded from the regression analyses because they showed significant correlation with other variables. The composition of amphipod assemblages between shores was compared using multidimensional scaling (MDS) on $\log _{10}$-transformed abundances, with the differences between shores being assessed by oneway ANOSIM (Clarke, 1993). Finally, we analysed the effect of structural variation in S. cymosum on the composition of amphipod assemblages using canonical correspondence analysis (CCA) for the complete dataset and separately for each shore. Independent variables were standardized before the analyses (Manly, 1994).

\section{Results}

PCA detected marked morphological variation among $S$. cymosum samples from the two shores (Figure 1). Axes 1-3 explained $72 \%$ of the variance, with the greatest difference between shores occurring in the second axis. Variables related to algal size, such as maximum length, leaf area, and wet mass, were most important at Perequê-Mirim, whereas at Fortaleza, algae were smaller and were more covered by sessile colonial animals (Table 1). The first axis detected large intra-shore variation among algae, particularly in holdfast diameter, number of primary stalks and secondary branches, and algal epiphytism (Table 1).

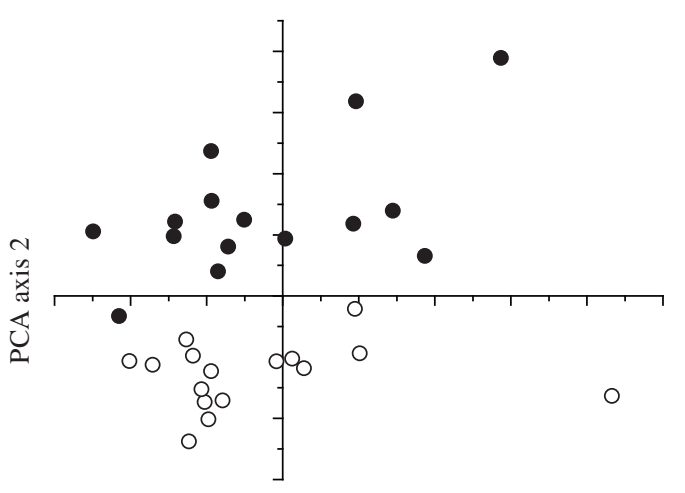

PCA axis 1

Figure 1. Ordination of the algal samples collected at Fortaleza (open circles) and Perequê-Mirim (solid circles) by PCA, based on structural characters of S. cymosum.

Table 1. Mean values ( \pm SE) of structural variables of $S$. cymosum at Fortaleza and Perequê-Mirim, and their loading on the first two axes of PCA.

\begin{tabular}{llcccc}
\hline \multicolumn{1}{c}{ Variable } & Symbol & Fortaleza & Perequê-Mirim & Axis 1 & Axis 2 \\
\hline Maximum diameter of the holdfast & DIAM & $1.80 \pm 0.21$ & $1.65 \pm 0.09$ & 0.458 & -0.031 \\
Minimum diameter of the holdfast & DIAMEN & $1.13 \pm 0.12$ & $1.12 \pm 0.08$ & 0.436 & 0.035 \\
Maximum length & LENG & $7.5 \pm 0.4$ & $24.1 \pm 1.3$ & -0.101 & 0.488 \\
Number of primary stalks & NR1 & $6.88 \pm 0.84$ & $5.93 \pm 0.59$ & 0.362 & -0.038 \\
Number of secondary branches & NR2 & $26.2 \pm 3.3$ & $22.5 \pm 2.3$ & 0.334 & 0.024 \\
Diameter of the primary stalks at the base & DB1 & $0.28 \pm 0.03$ & $0.25 \pm 0.02$ & 0.159 & -0.155 \\
Diameter of the primary stalks in the & DM1 & $0.24 \pm 0.02$ & $0.21 \pm 0.02$ & 0.272 & -0.074 \\
intermediate region & & & & \\
Diameter of the primary stalks at the bifurcation & DP1 & $0.24 \pm 0.02$ & $0.22 \pm 0.01$ & 0.213 & -0.141 \\
Leaf area & LA & $14.0 \pm 1.9$ & $81.8 \pm 15.9$ & 0.087 & 0.498 \\
Epiphytism by algae & EPFA & $1.13 \pm 0.30$ & $1.93 \pm 0.41$ & 0.305 & 0.259 \\
Epiphytism by sessile colonial animals & EPFB & $2.81 \pm 0.29$ & $0.80 \pm 0.38$ & 0.243 & -0.395 \\
Wet mass & MASS & $6.0 \pm 0.9$ & $23.1 \pm 3.5$ & 0.209 & 0.487 \\
\hline
\end{tabular}


We collected 223 amphipods, which represented $23 \%$ of the total fauna at Fortaleza and $51 \%$ at PerequêMirim. There were no significant differences in the structure of the amphipod assemblages between the two shores (Student's $t$ test, df $=29, \mathrm{p}>0.15$ for all comparisons), with similar estimates of abundance and diversity (Table 2). However, within each shore, different algal characteristics influenced these estimates. The abundance of amphipods at Perequê-Mirim was influ- enced by algal epiphytism and sessile colonial animals, whereas at Fortaleza, the diameter of primary stalks at the first bifurcation and wet mass influenced the abundance (Table 3). On both shores, species richness was influenced by the extent of cover by sessile colonial animals, but at Perequê-Mirim the basal diameter of the primary stalks had a weak effect (Table 3 ). Finally, the Shannon-Weaver diversity index was influenced by different variables on each shore, i.e., the basal diameter

Table 2. Composition of the amphipod assemblages associated with $S$. cymosum on the shores studied, and estimates of the diversity and total abundance for each shore. $\mathrm{N}=$ free-living nestler; $\mathrm{T}=$ tube-builder; $\mathrm{I}=$ inquiline; and $\mathrm{B}=$ burrower.

\begin{tabular}{|c|c|c|c|c|c|c|}
\hline \multirow[t]{2}{*}{ Species } & \multirow[t]{2}{*}{ Symbol } & \multirow[t]{2}{*}{ Life habit } & \multicolumn{2}{|c|}{ Fortaleza } & \multicolumn{2}{|c|}{ Perequê-Mirim } \\
\hline & & & Mean $\pm \mathrm{SE}$ & $\%$ & Mean $\pm \mathrm{SE}$ & $\%$ \\
\hline Amphilocus neapolitanus Della Valle & Amphi & $\mathrm{N}$ & $0.06 \pm 0.06$ & 1.3 & 0 & 0.0 \\
\hline Ampithoe ramondi (Audouin) & Amp & $\mathrm{T}$ & $0.06 \pm 0.06$ & 1.3 & $0.40 \pm 0.27$ & 4.1 \\
\hline Batea catharinensis Muller & Bat & $\mathrm{N}$ & $0.13 \pm 0.13$ & 2.6 & 0 & 0.0 \\
\hline Podocerus sp. & Pod & $\mathrm{T}$ & 0 & 0.0 & $0.27 \pm 0.12$ & 2.7 \\
\hline Corophium acherusicum Costa & Cor & $\mathrm{T}$ & $0.06 \pm 0.06$ & 1.3 & $0.20 \pm 0.14$ & 2.1 \\
\hline Cymadusa filosa (Savigny) & Cym & $\mathrm{T}$ & $1.25 \pm 0.41$ & 26.0 & $0.13 \pm 0.09$ & 1.4 \\
\hline Elasmopus brasiliensis Dana & Ela_bra & $\mathrm{N}$ & $0.13 \pm 0.13$ & 2.6 & 0 & 0.0 \\
\hline Elasmopus pectenicrus (Bate) & Ela_pec & $\mathrm{N}$ & 0 & 0.0 & $0.20 \pm 0.11$ & 2.1 \\
\hline Ericthonius brasiliensis (Dana) & Eri & $\mathrm{T}$ & $0.25 \pm 0.17$ & 5.2 & 0 & 0.0 \\
\hline Hyale nigra (Haswell) & Hya & $\mathrm{N}$ & $0.44 \pm 0.16$ & 9.1 & $1.13 \pm 0.62$ & 11.6 \\
\hline Jassa slatteryi Conlan & Jas & $\mathrm{T}$ & $0.06 \pm 0.06$ & 1.3 & 0 & 0.0 \\
\hline Lembos sp. & Lem & $\mathrm{T}$ & $0.06 \pm 0.06$ & 1.3 & $0.20 \pm 0.14$ & 2.1 \\
\hline Leucothoe spinicarpa (Abildgaard) & Leu & I & $0.31 \pm 0.12$ & 6.5 & 0 & 0.0 \\
\hline Shoemakerella nasuta Dana & Sho & $\mathrm{B}$ & $0.19 \pm 0.10$ & 3.9 & $0.73 \pm 0.43$ & 7.5 \\
\hline Stenothoe valida (Dana) & Ste & I & $0.44 \pm 0.20$ & 9.1 & $5.33 \pm 3.46$ & 54.8 \\
\hline Sunampithoe pelagica (Milne Edwards) & Sun & $\mathrm{T}$ & $1.31 \pm 0.45$ & 27.3 & $1.13 \pm 0.46$ & 11.6 \\
\hline Unidentified juvenile & sp1 & & $0.06 \pm 0.06$ & 1.3 & 0 & 0.0 \\
\hline Total abundance & & & $3.72 \pm 2.21$ & & $4.05 \pm 3.65$ & \\
\hline Species richness & & & $2.81 \pm 1.38$ & & $2.33 \pm 1.18$ & \\
\hline Shannon-Wiener index & & & $0.83 \pm 0.55$ & & $0.58 \pm 0.40$ & \\
\hline
\end{tabular}

Table 3. The influence of the structural characteristics of $S$. cymosum on amphipod total abundance, species richness, and the Shannon-Weaver diversity index for each shore, as assessed by stepwise multiple regression. Symbols: DB1 - diameter of the primary stalks at the base; DP1 - diameter of the primary stalks at the bifurcation; EPFA- epiphytism by algae; EPFB - epiphytism by sessile colonial animals; MASS - wet mass.

\begin{tabular}{|c|c|c|c|c|c|c|c|c|}
\hline & \multicolumn{4}{|c|}{ Fortaleza } & \multicolumn{4}{|c|}{ Perequê-Mirim } \\
\hline & Effect & Coefficient & SE & $\mathbf{p}$ & Effect & Coefficient & SE & $\mathbf{p}$ \\
\hline \multirow[t]{3}{*}{ Abundance } & $\mathrm{r}^{2}=0.70$ & & & & $\mathrm{r}^{2}=0.92$ & & & \\
\hline & DP1 & 16.68 & 7.50 & 0.044 & EPFA & 2.74 & 0.82 & 0.006 \\
\hline & MASS & 0.74 & 0.14 & $<0.001$ & EPFB & 9.57 & 0.88 & $<0.001$ \\
\hline \multirow[t]{3}{*}{ Richness } & $\mathrm{r}^{2}=0.31$ & & & & $\mathrm{r}^{2}=0.55$ & & & \\
\hline & EPFB & 0.66 & 0.26 & 0.025 & DB1 & 7.55 & 3.16 & 0.034 \\
\hline & & & & & EPFB & 0.56 & 0.16 & 0.004 \\
\hline \multirow[t]{2}{*}{ Shannon } & $\mathrm{r}^{2}=0.32$ & & & & $\mathrm{r}^{2}=0.35$ & & & \\
\hline & EPFB & 0.27 & 0.10 & 0.021 & DB1 & 3.19 & 1.21 & 0.020 \\
\hline
\end{tabular}


of primary stalks at Perequê-Mirim and cover by sessile colonial animals at Fortaleza (Table 3).

The composition of amphipod assemblages differed between shores, with more than half of the individuals at Fortaleza being from the species Cymadusa filosa and Sunampithoe pelagica, whereas at Perequê-Mirim a single species, Stenothoe valida, accounted for $54.8 \%$ of all individuals (Table 2). An analysis of life habits showed that there were two inquiline species at Fortaleza, Leucothoe spinicarpa and S. valida (16\% of all individuals), whereas only S. valida occurred at Perequê-Mirim. Free-living species contributed to $16 \%$ of all individuals at Fortaleza and $14 \%$ at Perequê-Mirim, whereas tubiculous species accounted for 64 and $24 \%$ of all individuals, respectively.

These differences in assemblage composition were reflected in the MDS results (Figure 2). Despite the large inter-sample variation for each shore, ANOSIM indicated significant differences between shores $(R=0.118$, $\mathrm{p}=0.02$ ). In addition, SIMPER analyses indicated that $60 \%$ of these differences was attributable to the greater abundance of S. pelagica and C. filosa at Fortaleza, and $S$. valida and $H$. nigra at Perequê-Mirim.

Different structural aspects influenced the assemblage composition between the shores studied. The first three axes of the CCA explained 57 and $69 \%$ of the variation at Fortaleza and Perequê-Mirim, respectively. The first axis at Fortaleza separated the diameter and number of primary stalks and the cover by sessile colonial animals from the other variables, while the second axis separated the maximum length and basal diameter of primary stalks from the other variables (Figure 3). Inquiline species were more associated with cover by sessile colonial animals, whereas variables associated with more complex morphologies influenced both nestlers and tube-builders. In contrast, the species were less separated by algal characteristics at Perequê-Mirim. The first axis contrasted the maximum diameter of the holdfast, maximum length, and number of primary stalks to the other variables, while the second axis separated the minimum diameter of the hold-

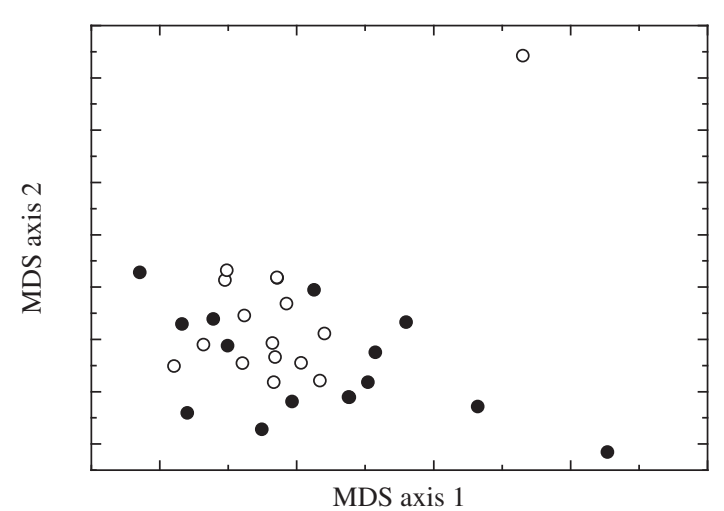

Figure 2. Ordination of amphipod assemblages associated with S. cymosum at Fortaleza (open circles) and PerequêMirim ( solid circles) by MDS. Stress $=0.15$. fast and diameter of primary stalks from the other variables (Figure 3). However, only Elasmopus pectenicrus and Lembos sp. were associated with small algae that had few secondary branches (Figure 3).
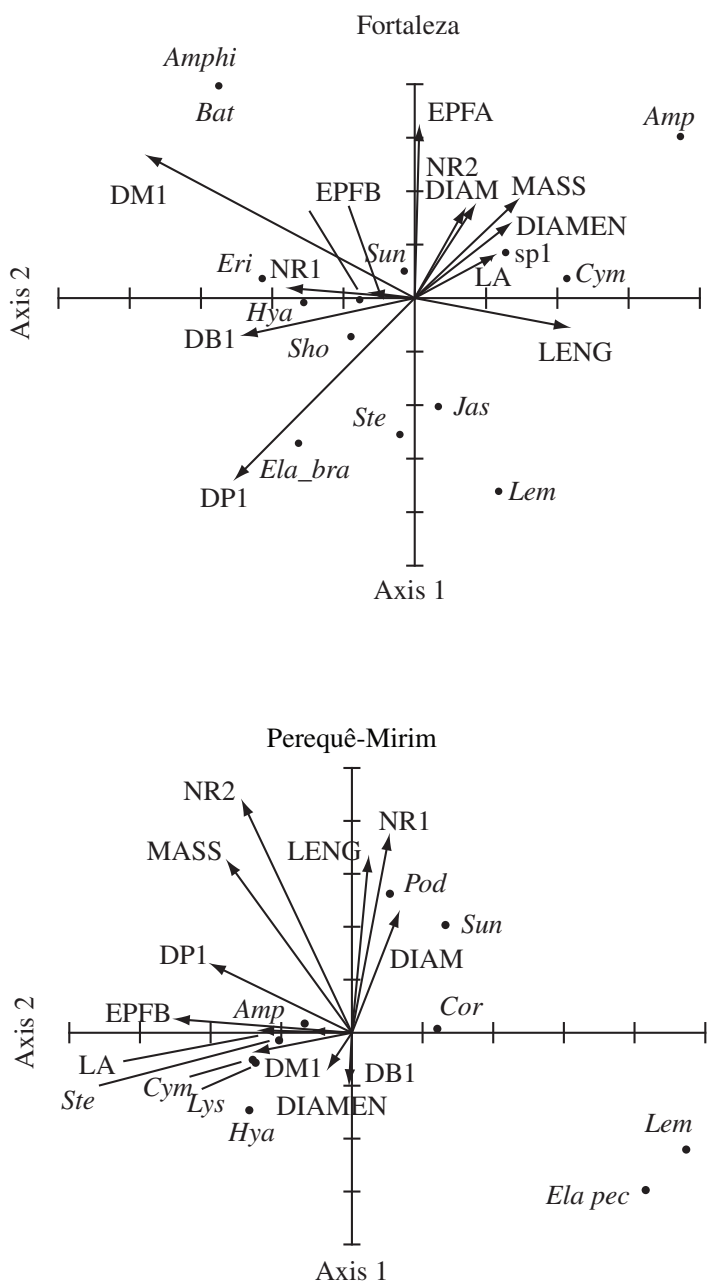

Figure 3. CCA relating amphipod assemblages and structural characteristics of S. cymosum at Fortaleza and PerequêMirim. Symbols: DIAM - maximum diameter of the holdfast; DIAMEN - minimum diameter of the holdfast; LENG maximum length; NR1 - number of primary stalks; NR2 number of secondary branches; DB1 - diameter of the primary stalks at the base; DM1 - diameter of the primary stalks in the intermediate region; DP1 - diameter of the primary stalks at the bifurcation; LA - leaf area; EPFA - epiphytism by algae; EPFB - epiphytism by sessile colonial animals; and MASS - wet mass; Amphi (Amphilocus neapolitanus); Amp (Ampithoe ramondi); Bat (Batea catharinensis); Pod (Podocerus sp.); Cor (Corophium acherusicum); Cym (Cymadusa filosa); Ela_bra (Elasmopus brasiliensis); Ela_ pec (Elasmopus pectenicrus); Eri (Ericthonius brasiliensis); Hya (Hyale nigra); Jas (Jassa slatteryi); Lem (Lembos sp.); Leu (Leucothoe spinicarpa); Sho (Shoemakerella nasuta); Ste (Stenothoe valida); Sun (Sunampithoe pelagica); sp1 (Unidentified juvenile). 


\section{Discussion}

Sargassum species can show large variation in size as a function of environmental characteristics such as hydrodynamics (Paula and Oliveira-Filho, 1982; Paula, 1988). In addition, strong morphological variation can also occur within shores that vary little in their characteristics (Széchy and Paula, 1998). As shown in the present study, most of the variance among $S$. cymosum specimens was attributable to structural variation in algae found within shores. Hence, the differences between shores were more related to algal size, whereas within shores there was marked variation among the algae collected so that different individuals of $S$. cymosum could provide different resources for the amphipods.

The effect of algal structural complexity on the mobile epifauna has been best studied in relation to algal size, and a positive relationship between substrate size and faunal species richness and abundance is frequently observed (Gunnill, 1982b; Russo, 1990). However, in the present study, the algal size influenced amphipod abundance only at Fortaleza, whereas cover by sessile colonial animals had a major influence on both shores. Sessile species such as hydrozoans and sponges can colonize the holdfast and branches of S. cymosum so that a second biological substrate may be used by the mobile epifauna. Indeed, the occurrence of inquiline species such as $L$. spinicarpa and $S$. valida was associated with the presence of these colonies and contributed to amphipod species richness observed in the samples, as suggested by Tanaka and Leite (2003). The basal diameter of primary stalks also influenced the number of species, and could be related to a larger area for colonization by sessile animals. These findings indicated that algal individuals are not necessarily homogeneous and that the presence of biological substrates can influence the interactions between amphipods and algal hosts. The ecological relationships among different species that can be used as biological substrates require additional investigation in order to clarify the patterns of local diversity (e.g., Parker et al., 2001).

The variations in algal characteristics and amphipod assemblages between shores seen in this study were expected because of differences in wave exposure. The morphological variation in S. cymosum between sheltered and exposed shores was analysed by Paula and Oliveira-Filho (1982), whereas the effect of hydrodynamics on amphipod assemblages has been described in other studies carried out in this region (Tararam and Wakabara, 1981, Wakabara et al., 1983) and elsewhere (Fenwick, 1976). However, the within-shore variation in amphipod assemblages was very large. Variation on spatial scales of 1-10 m can be common (Tanaka and Leite, 2003) and may be related to structural differences among algal hosts.

Differences in amphipod assemblages among algae within a shore can be related to algal patch size and to their relative position on the rocky shore (Gunnill, 1982a), phenological differences among individuals
(Sanchez-Moyano et al., 2001), or morphological differences among individuals, as in the case of seagrasses (Horinouchi and Sano, 1999). In the present study, variables related to algal complexity, such as the number and diameter of primary stalks, holdfast size, and cover by sessile colonial animals, influenced the species distribution. Higher structural complexity may provide greater diversity and abundance of spaces that can be used by amphipods as shelter against exposure to waves (Fenwick, 1976). In this case, the number and diameter of primary stalks can directly influence the species abundance and distribution, whereas holdfast size and cover of sessile species may facilitate the occurrence of species with inquiline life habits (Dubiaski-Silva and Masunari, 1995). Consequently, the structural complexity of the alga would be increased, with greater availability of structures for amphipod fixation, thereby reducing the competition for biological substrates. Understanding the factors that promote intraspecific structural diversity in Sargassum banks (e.g., Széchy and Paula, 2000) will be of great value in explaining the distribution of the mobile epifauna on a local scale.

Acknowledgments - F. P. P. Leite was supported by CNPq (PQ. No 300337/82-5) and FAEP-UNICAMP. R. S. Gebara was supported by FAPESP (IC Fellowship No. 97/00945-0). Dr. S. Hyslop revised the English text.

\section{References}

ATTRILL, MJ., STRONG, JA. and ROWDEN, AA., 2000. Are macroinvertebrate communities influenced by seagrass structural complexity? Ecography, vol. 23, no. 1, p. 114-121.

CLARKE, KR., 1993. Non-parametric multivariate analysis of changes in community structure. Austral. J. Ecol., vol. 18, no. 1, p. 117-143.

DOWNES, BJ., LAKE, PS., SCHREIBER, ESG. and GLAISTER, A., 2000. Habitat structure, resources and diversity: the separate effects of surface roughness and macroalgae on stream invertebrates. Oecologia, vol. 123, no. 4, p. 569-581.

DUBIASKI-SILVA, J. and MASUNARI, S., 1995. Ecologia populacional dos Amphipoda (Crustacea) dos fitais de Caiobá, Matinhos, Paraná, Brasil. Rev. Bras. Zool., vol. 12, no. 2, p. 373-396.

EDGAR, GJ., 1983. The ecology of south-east Tasmanian phytal animal communities. I. Spatial organization on a local scale. J. Exp. Mar. Biol. Ecol., vol. 70, no. 2, p. 129-157.

FENWICK, GD., 1976. The effect of wave exposure on the amphipod fauna of the alga Caulerpa brownii. J. Exp. Mar. Biol. Ecol., vol. 25, no. 1, p. 1-18.

FLYNN, MN., TARARAM, AS. and WAKABARA, Y., 1996. Effects of habitat complexity on the structure of macrobenthic association in a Spartina alterniflora marsh. Rev. Bras. Oceanogr., vol. 44, no. 1, p. 9-21.

GEE, J. and WARWICK, R., 1994. Metazoan community structure in relation to the fractal dimensions of marine macroalgae. Mar. Ecol. Prog. Ser., vol. 103, p. 141-150.

GUNNILL, FC., 1982a. Effects of plant size and distribution on numbers of invertebrate species and individuals inhabiting 
the brown alga Pelvetia fastigiata. Mar. Biol., vol. 69, no. 3, p. 263-280.

GUNNILL, FC., 1982b. Macroalgae as habitat patch islands for Scutellidium lamellipes (Copepoda) and Ampithoe tea (Amphipoda). Mar. Biol., vol. 69, no. 1, p. 103-116.

HACKER, SD. and STENECK, RS., 1990. Habitat architecture and the abundance and body-size-dependent habitat selection of a phytal amphipod. Ecology, vol. 71, no. 3, p. 2269-2285.

HALL, MO. and BELL, SS., 1988. Response of small motile epifauna to complexity of epiphytic algae on seagrass blades. $J$. Mar. Res., vol. 46, p. 613-630.

HAY, ME., DUFFY, JE., PFISTER, CA. and FENICAL, W., 1987. Chemical defense against different marine herbivores: are amphipods insect equivalents? Ecology, vol. 68, no. 6, p. $1567-1580$

HOLMQUIST, JG.,1997. Disturbance and gap formation in a marine benthic mosaic: influence of shifting macroalgal patches on seagrass structure and mobile invertebrates. Mar. Ecol. Prog. Ser, vol. 158, p. 121-130.

HORINOUCHI, M. and SANO, M.,1999. Effects of changes in seagrass shoot density and leaf height on abundances and distribution patterns of juveniles of three gobiid fishes in a Zostera marina bed. Mar. Ecol. Prog. Ser., vol. 183, p. 87-94.

HULL, SL., 1997. Seasonal changes in diversity and abundance of ostracodes on four species of intertidal algae with differing structural complexity. Mar. Ecol. Prog. Ser., vol. 161, p. 71-82.

JENKINS, GP., WALKER-SMITH, GK. and HAMER, PA., 2002. Elements of habitat complexity that influence harpacticoid copepods associated with seagrass beds in a temperate bay. Oecologia, vol. 131, no. 4, p. 598-605.

JENKINS, GP. and WHEATLEY, MJ., 1998. The influence of habitat structure on nearshore fish assemblages in a southern Australian embayment: comparison of shallow seagrass, reefalgal and unvegetated sand habitats, with emphasis on their importance to recruitment. J. Exp. Mar. Biol. Ecol., vol. 221, no. 2, p. $147-172$.

JERNAKOFF, P., BREARLEY, A. and NIELSEN, J., 1996. Factors affecting grazer-epiphyte interactions in temperate seagrass meadows. Oceanogr. Mar. Biol. Annu. Rev., vol. 34, p. $109-162$.

JERNAKOFF, P. and NIELSEN, J., 1998. Plant-animal associations in two species of seagrasses in western Australia. Aquat. Bot., vol. 60, no. 4, p. 359-376.

JORMALAINEN, V., HONKANEN, T. and HEIKKILA, N., 2001. Feeding preferences and performance of a marine isopod on seaweed hosts: cost of habitat specializationo. Mar. Ecol. Prog. Ser. vol. 220, p. 219-230.

KELAHER, BP., 2003a. Changes in habitat complexity negatively affect diverse gastropod assemblages in coralline algal turf. Oecologia, vol. 135, no. 3, p. 431-441.
-, 2003b. Effects of frond length on diverse gastropod assemblages in coralline turf. J. Mar. Biol. Ass. U. K., vol. 83, no. 1, p. $159-163$.

MANLY, BFJ., 1994. Multivariate statistical method: a primer. 2nd ed. Chapman and Hall, Londono.

MONTEIRO, SM., CHAPMAN, MG. and UNDERWOOD, AJ., 2002. Patches of the ascidian Pyura stolonifera (Heller, 1878): structure of habitat and associated intertidal assemblages. J. Exp. Mar. Biol. Ecol., vol. 270, no. 2, p. 171-189.

PARKER, JD., DUFFY, JE. and ORTH, RJ., 2001. Experimental tests of plant diversity effects on epifaunal diversity and production in a temperate seagrass bed. Mar. Ecol. Progr. Ser., vol. 224, p. 55-67.

PAULA, EJ., 1988. O gênero Sargassum C. Ag. (Phaeophyta - Fucales) no litoral do Estado de São Paulo, Brasil. Bolm. Bot., vol. 10, p. 65-118.

PAULA, EJ. and OLIVEIRA-FILHO, EC. 1982. Wave exposure and ecotypical differentiation in Sargassum cymosum (Phaeophyta - Fucales). Phycologia, vol. 21, no. 2, p. 145-153.

RUSSO, AR., 1990. The role of seaweed complexity in structuring Hawaiian epiphytal amphipod communities. Hydrobiologia, vol. 194, no. 1, p. 1-12.

SANCHEZ-MOYANO, JE., ESTACIO, FJ., GARCIAADIEGO, EM. and GARCIA-GOMEZ, JC., 2001. Effect of the vegetative cycle of Caulerpa prolifera on the spatio-temporal variation of invertebrate macrofauna. Aquat. Bot., vol. 70, no. 2, p. 163-174.

SCHREIDER, MJ., GLASBY, TM. and UNDERWOOD, AJ., 2003. Effects of height on the shore and complexity of habitat on abundances of amphipods on rocky shores in New South Wales, Australia. J. Exp. Mar. Biol. Ecol., vol. 293, no. 1, p. 57-71.

SZÉCHY, MTM. and PAULA, EJ., 1998. Tipos morfológicos em populações de Sargassum (Phaeophyta-Fucales) do litoral dos Estados do Rio de Janeiro e São Paulo, Brasil. Leandra, no. 13 , p. $29-43$.

-, 2000. Padrões estruturais e quantitativos de bancos de Sargassum (Phaeophyta, Fucales) do litoral dos estados do Rio de Janeiro e São Paulo, Brasil. Rev. Bras. Bot., no. 2, p. 121-132.

TANAKA, MO. and LEITE, FPP., 2003. Spatial scaling in the distribution of macrofauna associated with Sargassum stenophyllum (Mertens) Martius: analyses of faunal groups, gammarid life habits, and assemblage structure. J. Exp. Mar. Biol. Ecol., vol. 293, no. 1, p. 1-22.

TARARAM, AS. and WAKABARA, Y., 1981. The mobile fauna - especially Gammaridea - of Sargassum cymosum. Mar. Ecol. Prog. Ser., vol. 5, p. 157-163.

WAKABARA, Y., TARARAM, AS. and TAKEDA, AM., 1983. Comparative study of the amphipod fauna living on Sargassum of two Itanhaém shores, Brazil. J. Crust. Biol., vol. 3, no. 4, p. 602-607. 
